\title{
Synthesis and Sinterability of Hydroxyapatite from Fishery by-products
}

\author{
Yusuf Wibisono****, Ni Luh Bella Dwijaksara***, Wahyu Bambang Widayatno*****, \\ Agus Sukarto Wismogroho*****, Muhamad Ikhlasul Amal******, Nurul Taufiqu Rochman*****, \\ Toshiyuki Nishimura ${ }^{* * * * * * * *}$, and Alfian Noviyanto ${ }^{* * * * * * * * *, * * * * * * * * * * * ;}$ \\ *Department of Bioprocess Engineering, Brawijaya University, Jl. Veteran, Malang 65145, Indonesia \\ **MILI Water Research Institute, PO BOX 301 ML, Malang 65101, Indonesia \\ ***Graduate School of Biomedical Engineering, Airlangga University, Jl. Airlangga 4-6, Surabaya 60286, Indonesia \\ ${ }^{* * * *}$ Research Center for Physics, Indonesian Institute of Sciences, PUSPIPTEK Tangerang Selatan, Banten 15314, Indonesia \\ ${ }_{* * * * *}$ Research Center for Metallurgy and Materials, Indonesian Institute of Sciences, PUSPIPTEK Tangerang Selatan, \\ Banten 15314, Indonesia \\ ******National Institute for Materials Science, 1 - 1 Namiki, Tsukuba, Ibaraki 305-0044, Japan \\ ******Department of Mechanical Engineering, Mercu Buana University, Jl. Meruya Selatan, Kebun Jeruk, \\ Jakarta Barat 11650, Indonesia \\ *******Nano Center Indonesia, Jl. PUSPIPTEK Tangerang Selatan, Banten 15314, Indonesia
}

(Received July 10, 2018; Revised September 28, 2018; Accepted September 28, 2018)

\begin{abstract}
Hydroxyapatites (HAps) were synthesized using the powdered waste of fishery products, i.e., fish scales and crab shells, as starting materials. HAp was synthesized by a wet-chemistry method followed by calcination at 600 and $800^{\circ} \mathrm{C}$. Calcined crabshell powder revealed a single HAp phase and fine powder, while calcined fish-scale powder showed a 8-TCP secondary phase, even at the higher calcination temperature. Dense HAp pellets were obtained from the crab-shell powder by spark plasma sintering at $1000^{\circ} \mathrm{C}$ for 10 min under applied pressures of 40 and $80 \mathrm{MPa}$ in a vacuum state, giving sample densities of 2.93 and $3.06 \mathrm{~g} / \mathrm{cm}^{3}$, respectively. The estimated grain size of HAp was $448 \pm 96$ and $283 \pm 59 \mathrm{~nm}$ for applied pressures of 40 and $80 \mathrm{MPa}$, respectively. In contrast, the HAp obtained using the pressureless sintering technique showed excessive grain growth without further densification.
\end{abstract}

Key words : Hydroxyapatite, Fish scales, Crab shells, Calcination, Sintering

\section{Introduction}

A biomaterial can be defined as a bio-based material or value-added biological material utilized for food, feed, fuel, pharmaceutical, or nutraceutical application. By definition, a biomaterial is also a bioproduct. A further definition is that a biomaterial is a non-viable material that is commonly used for the augmentation of organs or as medical devices. All materials made from metals, polymers, ceramics, or bio-based materials can be utilized as biomaterials, provided they comply with the biocompatibility requirements. ${ }^{1)}$ Biocompatibility means that the material must be able to interact with living systems without harming its surrounding biological systems.

HAp of the chemical formula $\mathrm{Ca}_{10}\left(\mathrm{PO}_{4}\right)_{6}(\mathrm{OH})_{2}$ is the main constituent component of hard tissue, such as bone and teeth, in the human body, and has superior biocompatibility. ${ }^{2)}$ HAp can be synthesized from natural calcium-rich resources and employed for hard tissue regeneration, bone scaffolds, functional particles, and ceramic membranes for

\footnotetext{
${ }^{\top}$ Corresponding author : Alfian Noviyanto

E-mail : a.noviyanto@nano.or.id

Tel : +62-818-758275 Fax : +62-21-587-1335
}

protein or lipid purifications. $^{3-5)}$

Traditionally, HAp is synthesized by mixing the calcium precursor with a phosphate precursor. Some studies utilized wet-chemistry methods, such as sol-gel and hydrothermal, to synthesize HAp. ${ }^{6-9)}$ In addition to the existing chemical methods, HAp can also be synthesized using waste materials such as crab shells, sea shells, fish scales, fish bones, and coral, ${ }^{8,10-19)}$ because the major elements of these natural materials are similar to those of HAp. As a maritime country, Indonesia has numerous fishery industries with abundant by-products such as fish scales and crab shells. To date, the utilization of these by-products for advanced products has been limited. Therefore, the utilization of these byproducts as raw materials for the synthesis of HAp may increase the economic value of these waste materials.

Mondal et $a l .{ }^{16)}$ reported the sintering of HAp from fish scales at $1200^{\circ} \mathrm{C}$ with a pressureless sintering technique. To decrease the sintering temperature, the use of pressureassisted sintering is imperative. For instance, the typical sintering temperatures of $\mathrm{SiC}$ or its composites are $2100-$ $2500^{\circ} \mathrm{C}$ and can be decreased to $1750^{\circ} \mathrm{C}$ using a hot-pressing vacuum furnace ${ }^{20)}$ or spark plasma sintering. ${ }^{21)}$ Thus, dense and transparent HAps were successfully fabricated by spark plasma sintering at a relatively low temperature com- 
pared to pressureless sintering techniques. ${ }^{22-26)}$ However, only a few records have been found on the pressure-assisted sintering of HAp from natural resources or waste material.

To the authors' knowledge, there are no detailed studies that have investigated the synthesis and sinterability of HAp from fishery by-products. Thus, the aim of this study is to obtain HAp from the waste of fishery products, as well as to investigate the role of sintering technique, such as pressureless sintering and pressure-assisted sintering, i.e., spark plasma sintering. We used fish scales and crab shells as the starting materials. The data for the phase analysis, microstructure, density, and mechanical properties are presented and discussed in detail to obtain a better understanding of the role of pressure in the properties of sintered HAp.

\section{Experimental Procedure}

Fish scales (Nemipterus nematophorus) and crab shells (Portunus pelagicus) as precursors for this study were obtained from Kelola Mina Laut Company, Indonesia. Crab shells and fish scales were boiled in water for $30 \mathrm{~min}$, and then washed using distilled water at room temperature. The as-washed crab shells and fish scales were stirred in a $1 \% \mathrm{NaOH}$ solution for $2 \mathrm{~h}$ and left overnight. Prior to sterilization in an autoclave at $110^{\circ} \mathrm{C}$ for $5 \mathrm{~h}$, the crab shells and fish scales were washed with distilled water. Herein, $\mathrm{CaO}$ powder was obtained by calcining the crab shells and fish scales at $1000^{\circ} \mathrm{C}$ for $5 \mathrm{~h}$. Then, approximately 50 and $90 \mathrm{~g}$ of calcined crab shells and fish scales, respectively, were dissolved in $200 \mathrm{~mL}$ of distilled water. The suspensions were then reacted with 0.21 and $0.04 \mathrm{~mol}$ of $85 \% \mathrm{H}_{3} \mathrm{PO}_{4}$, respectively. The $\mathrm{pH}$ was maintained at 10 during stirring for $1 \mathrm{~h}$ at $60^{\circ} \mathrm{C}$. After $24 \mathrm{~h}$ of aging at $27^{\circ} \mathrm{C}$, the precipitate was filtered and dried at $110^{\circ} \mathrm{C}$ for $5 \mathrm{~h}$. The dried samples were calcined at 600 and $800^{\circ} \mathrm{C}$ for $5 \mathrm{~h}$ in an air atmosphere to obtain HAp powder. The HAp powder obtained from crab shells (named CHAp) was poured into a $15 \mathrm{~mm}$ graphite die and sintered at $1000^{\circ} \mathrm{C}$ for $10 \mathrm{~min}$ at uniaxial pressures of 40 and $80 \mathrm{MPa}$ in a vacuum state via spark plasma sintering with heating and cooling rates of $20^{\circ} \mathrm{C} \mathrm{min}{ }^{-1}$. The sintered HAp was black owing to carbon contamination from the graphite die. To eliminate the carbon, the sintered HAp was heat-treated at $800^{\circ} \mathrm{C}$ for $2 \mathrm{~h}$ in an air atmosphere. For comparison purposes, CHAp was also sintered using a pressureless sintering method at 1000,1100 , and $1200^{\circ} \mathrm{C}$ for $5 \mathrm{~h}$ in the ambient condition.

The element compositions of the calcined crab shells and fish scales were determined using X-ray fluorescence (XRF: Minipal 4, PANalytical, The Netherlands). The phases of the calcined powder as well as sintered pellets, were investigated using room-temperature X-ray diffraction (XRD: X'Pert-PRO MPD, PANalytical, The Netherlands) with the $\mathrm{Cu}-\mathrm{Ka}$ line. The densities of the sintered samples were measured using the Archimedes principle. The morphologies of the powder particles and sintered bodies were observed using scanning electron microscopy (SEM: S-4800, Hitachi, at $10 \mathrm{kV}$ and $10 \mu \mathrm{A})$. The average particle and grain sizes were estimated from the SEM images and analyzed statistically.

\section{Results and Discussion}

Table 1 shows the elemental compositions of the calcined crab shells and fish scales sintered at $1000^{\circ} \mathrm{C}$ for $5 \mathrm{~h}$. As shown, the major element is $\mathrm{Ca}$; the crab shells possess a higher Ca content (93.78\%) than fish scales (82.31\%). In contrast, the fish scales have a higher phosphor content than its counterpart. These results indicate that both fish scales and crab shells are potential candidates as raw materials for HAp production. However, further work is required to eliminate their impurities.

Figure 1 shows the XRD patterns of HAp powder from crab shells (CHAp) and fish scales (FHAp) after calcination at 600 and $800^{\circ} \mathrm{C}$ for $5 \mathrm{~h}$. As shown in Figs. 1(a) and (b), only hydroxyapatite $\left(\mathrm{Ca}_{10}\left(\mathrm{PO}_{4}\right)_{6}(\mathrm{OH})_{2}\right)$ is observed without any trace of secondary phases for CHAp, even at low calcination temperatures $\left(600^{\circ} \mathrm{C}\right)$. The crystallization of $\mathrm{CHAp}$ is improved with higher calcination temperature, as shown in Fig. 1(b). On the contrary, secondary phases ( $\beta$-tricalcium

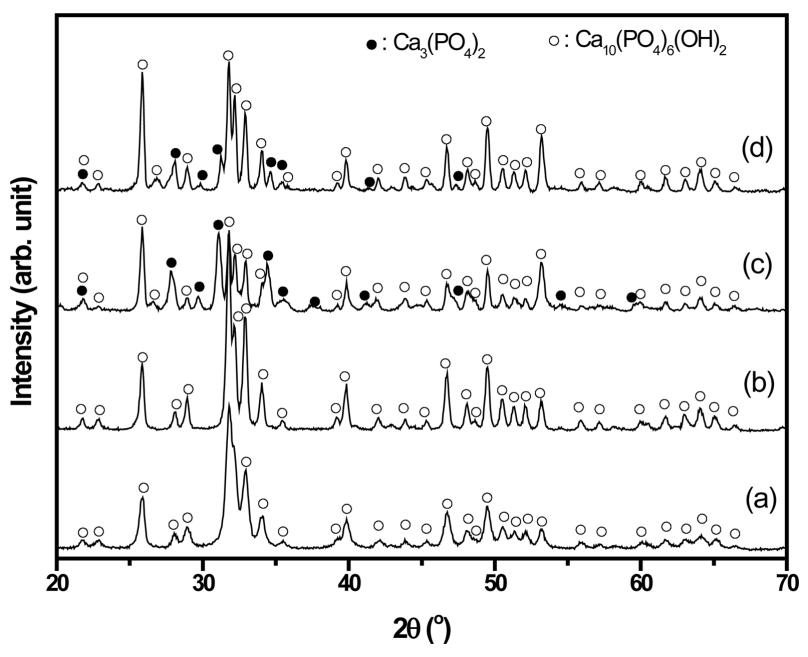

Fig. 1. XRD of calcined powder of $\mathrm{CHAp}$ at (a) $600^{\circ} \mathrm{C}$ and (b) $800^{\circ} \mathrm{C}$; and $\mathrm{FHAp}$ at (c) $600^{\circ} \mathrm{C}$ and (d) $800^{\circ} \mathrm{C}$. The calcination time for both powders was $5 \mathrm{~h}$.

Table 1. Elemental Analysis (in wt. \%) of Crab Shells and Fish Scales After Calcination at $1000^{\circ} \mathrm{C}$ for $5 \mathrm{~h}$

\begin{tabular}{lcccccccc}
\hline & $\mathrm{Ca}$ & $\mathrm{P}$ & $\mathrm{Fe}$ & $\mathrm{Cu}$ & $\mathrm{Zr}$ & $\mathrm{Yb}$ & $\mathrm{Sr}$ & $\mathrm{Other}$ \\
\hline Fish scales & 82.31 & 15.8 & 0.088 & 0.053 & 0.2 & 0.27 & 1.1 & 0.179 \\
Crab shells & 93.78 & 1.6 & 0.108 & 0.057 & 0.1 & 0.61 & 3.33 & 0.415 \\
\hline
\end{tabular}



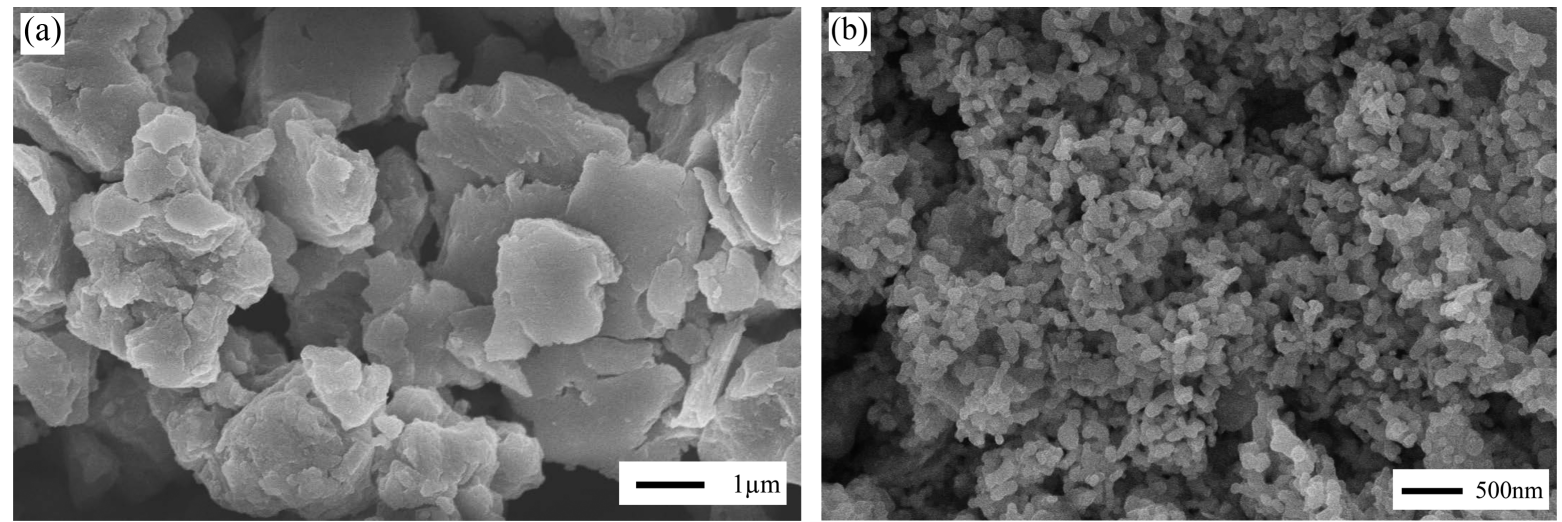

Fig. 2. SEM images of calcined powder at $800^{\circ} \mathrm{C}$ for $5 \mathrm{~h}$ (a) FHAp and (b) CHAp. Two different magnifications were used for convenience.
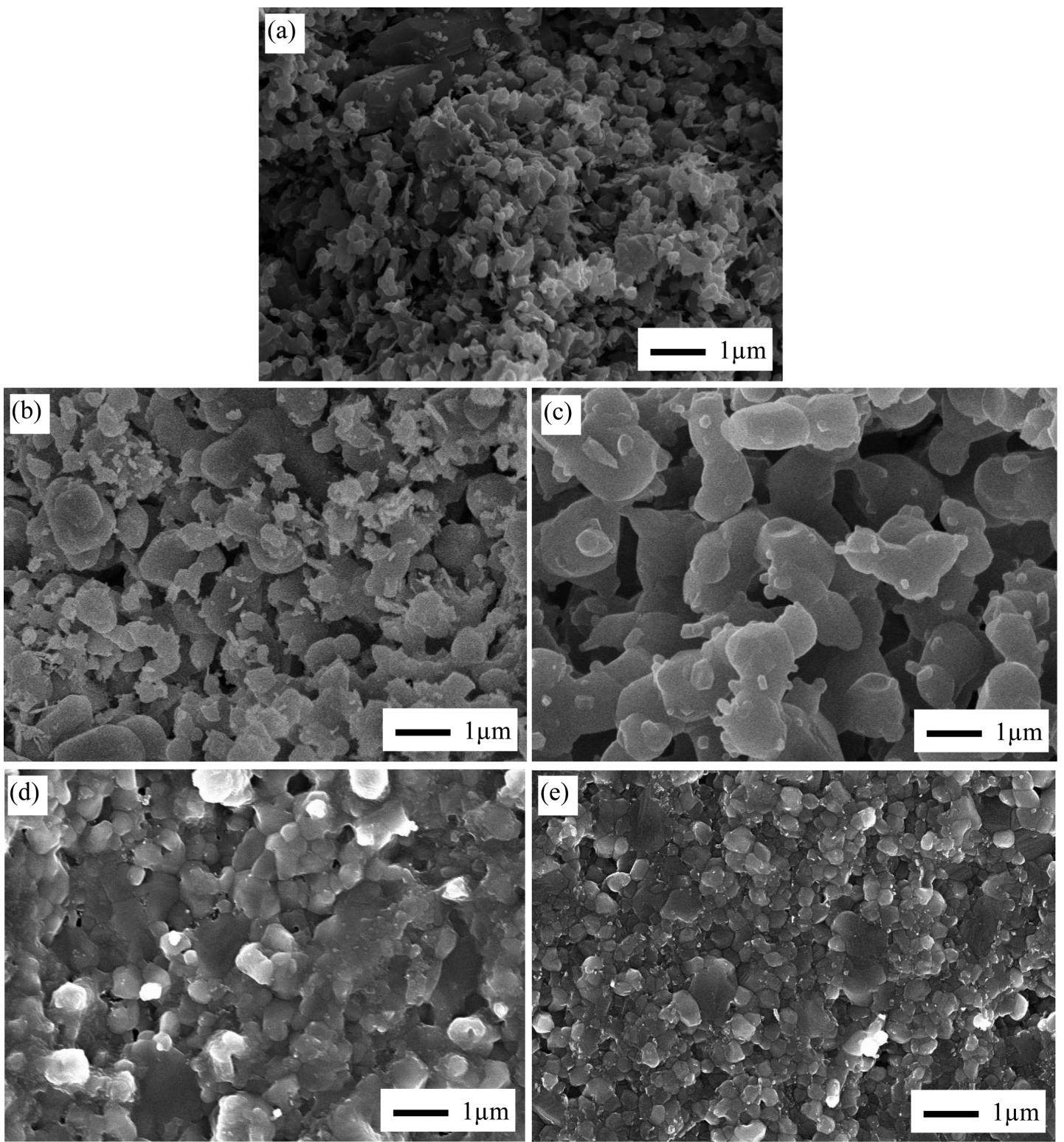

Fig. 3. SEM of sintered CHAp by pressureless sintering for $5 \mathrm{~h}$ at (a) $1000^{\circ} \mathrm{C}$, (b) $1100^{\circ} \mathrm{C}$, and (c) $1200^{\circ} \mathrm{C}$; and spark plasma sintering for $10 \mathrm{~min}$ at $1000^{\circ} \mathrm{C}$ in a vacuum under an applied pressure of (d) $40 \mathrm{MPa}$ and (e) $80 \mathrm{MPa}$. 
Table 2. Properties of Sintered CHAp

\begin{tabular}{cccccc}
\hline $\begin{array}{c}\text { SPS } \\
\text { Pressure }(\mathrm{MPa})\end{array}$ & $\begin{array}{c}\text { Grain size } \\
(\mathrm{nm})\end{array}$ & $\begin{array}{c}\text { Sintered density } \\
\left(\mathrm{g} / \mathrm{cm}^{3}\right)\end{array}$ & $\begin{array}{c}\text { Relative density } \\
(\%)\end{array}$ & $\begin{array}{c}\text { Hardness } \\
(\mathrm{GPa})\end{array}$ & $\begin{array}{c}\text { Fracture toughness } \\
\left(\mathrm{MPa} \mathrm{m}^{1 / 2}\right)\end{array}$ \\
\hline 40 & $448 \pm 96$ & 2.93 & 92.8 & $6.19 \pm 0.54$ & $5.68 \pm 0.12$ \\
80 & $283 \pm 59$ & 3.06 & 96.6 & $6.40 \pm 1.63$ & $4.23 \pm 0.35$ \\
\hline
\end{tabular}

phosphate $/ \beta$-TCP $\left./ \mathrm{Ca}_{3}\left(\mathrm{PO}_{4}\right)_{2}\right)$ are observed for both FHAp powders $\left(600\right.$ and $\left.800^{\circ} \mathrm{C}\right)$, as shown in Figs. 1(c) and (d). At $800^{\circ} \mathrm{C}$, the peaks of $\beta$-TCP are still observed, even though HAp phase becomes dominant. It is believed that the $\beta$-TCP phase would transform into the HAp phase with further calcination at higher temperature, since $\beta$-TCP is an unstable phase. ${ }^{27)}$ CHAp has a single phase owing to its finer particle size, as shown in Fig. 2(b). The finer particle size indicates a higher surface area, which leads to higher activity and ease of forming the single phase. Thus, HAp can be formed at lower temperature without the formation of the secondary phase, as displayed in Fig. 1(a).

Figure 2 presents the SEM images of FHAp and CHAp after calcination at $800^{\circ} \mathrm{C}$ for $5 \mathrm{~h}$. It is very clear that CHAp possesses a finer morphology than FHAp. FHAp and CHAp have a flat and round shape with a particle size of $>1 \mu \mathrm{m}$ and $105 \pm 28 \mathrm{~nm}$, respectively. The particle properties of CHAp show the typical results of the wet chemistry method, i.e., precipitation. Yet, FHAp reaches an unexpected particle size, which is likely due to the existing impurity of FHAp. Since the methods of synthesizing HAp from FHAp and CHAp are identical, this suggests that the difference in particle size of these powders is likely due to impurity content. As shown in Table 1, FHAp only has $82.31 \%$ of Ca compared to the $93.78 \%$ of Ca in CHAp. Moreover, the secondary phase is observed in FHAp, as shown in Fig. 1; it was not found in CHAp.

Figure 3 shows the SEM images of the fractured surface of sintered HAp. As shown in Figs. 3(a), (b), and (c), the pressureless sintering of CHAp shows no sign of densification. Although necking is observed in Fig. 3(c), pressureless sintering yields no further densification mechanisms in CHAp. It should be noted that the CHAp particle size grows significantly at a sintering temperature of $1200^{\circ} \mathrm{C}$ when the pressureless sintering method is used. In contrast, a dense CHAp microstructure is obtained using the spark plasma sintering method, as shown in Figs. 3(d) and (e). These pellets were sintered at $1000^{\circ} \mathrm{C}$ for $10 \mathrm{~min}$, indicating the effectiveness of spark plasma sintering in obtaining dense HAp in a short time and at a lower temperature in comparison with the conventional sintering method. Under the applied pressures of 40 and $80 \mathrm{MPa}$, the density of CHAp sintered at $1000^{\circ} \mathrm{C}$ reaches 2.93 and $3.06 \mathrm{~g} / \mathrm{cm}^{3}$, respectively, which corresponds to relative densities of $92.8 \%$ and $96.6 \%$, as shown in Table 2. The difference in density of the 40 and 80 MPa samples can be explained by the shrinkage of the samples, as shown in Fig. 4. The densification of HAp starts early at $760^{\circ} \mathrm{C}$ for the sample under a pressure of $80 \mathrm{MPa}$ compared to that under $40 \mathrm{MPa}$, which begins at $800^{\circ} \mathrm{C}$.

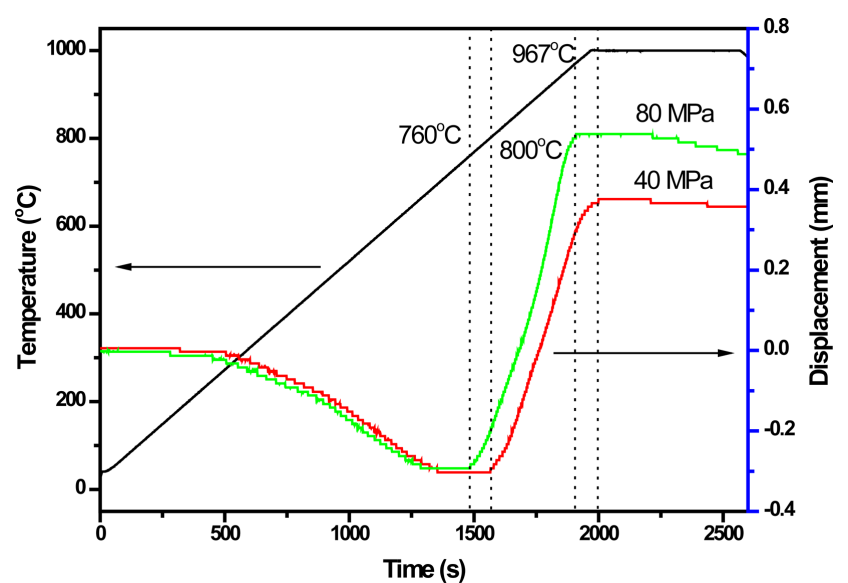

Fig. 4. Temperature and displacement of CHAp powder during sintering, as a function of time.

Furthermore, the densification of the HAp sample at 80 $\mathrm{MPa}$ stops at $967^{\circ} \mathrm{C}$, before the soaking time at $1000^{\circ} \mathrm{C}$. In contrast, the $40 \mathrm{MPa}$ sample shows that the densification stops at the beginning of the soaking time at $1000^{\circ} \mathrm{C}$. These data elucidate the effect of pressure is imperative to obtain a higher density of HAp.

The effects of pressure on the grain size are shown in the SEM images in Figs. 3(d) and (e). Indeed, a higher applied pressure i.e., $80 \mathrm{MPa}$, yields a smaller CHAp grain size. Table 2 presents the average grain size of $448 \pm 96$ and 283 $\pm 59 \mathrm{~nm}$ for sintered CHAp under the applied pressures of 40 and $80 \mathrm{MPa}$, respectively. The suppression of grain growth in Fig. 3(e) is likely due to the higher pressure, i.e., $80 \mathrm{MPa}$, which promotes densification while suppressing grain growth. Nevertheless, the hardness value of the sintered CHAp under different applied pressures does not differ (6.19 and 6.40 GPa for applied pressures of 40 and 80 $\mathrm{MPa}$, respectively). The higher hardness value of CHAp under the $80 \mathrm{MPa}$ applied pressure is likely due to the finer grain size than that of its counterpart. Table 2 reveals that under higher applied pressure, the indentation fracture toughness of CHAp is lower. In this regard, this result is in agreement with Furushima et al. ${ }^{28)}$ who reported a lower fracture toughness when the hardness of WC-FeAl increased. Launey and Ritchie ${ }^{29)}$ explained that materials with small-sized grains inhibit crack propagation, which lowers the toughness.

\section{Conclusions}

HAps were successfully synthesized from natural resources, 
i.e., crab shells, using spark plasma sintering at $1000^{\circ} \mathrm{C}$ for 10 min under applied pressures of 40 and $80 \mathrm{MPa}$ in a vacuum condition. The calcined crab-shell powder had an average particle size of $105 \pm 28 \mathrm{~nm}$, which is a typical result of the wet-chemistry method. Contrasting results were obtained for the calcined fish-scale powder, where large particle size and secondary phases of $\beta$-TCP were observed. Despite the higher temperature and longer sintering time $\left(1200^{\circ} \mathrm{C}\right.$ for $\left.5 \mathrm{~h}\right)$, densification of CHAp pellets did not occur during pressureless sintering. In contrast, dense CHAp pellets were obtained with spark plasma sintering at $1000^{\circ} \mathrm{C}$ for $10 \mathrm{~min}$. Moreover, a fine-grained microstructure was observed for spark plasma sintered CHAp under the applied pressures of 40 and $80 \mathrm{MPa}$, despite the lack of obvious difference in hardness. In conclusion, crab shell is an alternative to the existing HAp precursors, and further investigation is needed.

\section{Acknowledgements}

The authors would like to acknowledge Mr. Iqbal and Mrs. Sapta from Kelola Mina Laut Company for providing the fishery waste materials used in this study.

\section{REFERENCES}

1. Y. Wibisono, Biomaterial dan Bioproduk; p. 24, UB Press, Malang, 2017.

2. M. Markovic, B. Fowler, and M. Tung, "Preparation and Comprehensive Characterization of a Calcium Hydroxyapatite Reference Material," J. Res. Natl. Inst. Stand. Technol., 109 [6] 553-68 (2004).

3. S. Wu, J. Wang, L. Zou, L. Jin, Z. Wang, and Y. Li, “A Three-Dimensional Hydroxyapatite/Polyacrylonitrile Wcomposite scaffold designed for bone tissue engineering," RSC Adv., 8 [4] 1730-36 (2018).

4. J. Sun and L. Wu, "Polyether Sulfone/Hydroxyapatite Mixed Matrix Membranes for Protein Purification," Appl. Surf. Sci., 308 155-60 (2014).

5. Y. Wibisono, W. A. Nugroho, and T.-W. Chung, "Dry Degumming of Corn-Oil for Biodiesel Using a Tubular Ceramic Membrane," Procedia Chem., 9 210-19 (2014).

6. H. S. Liu, T. S. Chin, L. S. Lai, S. Y. Chiu, K. H. Chung, C. S. Chang, and M. T. Lui, "Hydroxyapatite Synthesized by a Simplified Hydrothermal Method," Ceram. Int., 23 [1] 19-25 (1997).

7. M. C. Barbosa, N. R. Messmer, T. R. Brazil, F. R. Marciano, and A. O. Lobo, "The Effect of Ultrasonic Irradiation on the Crystallinity of Nano-Hydroxyapatite Produced via the Wet Chemical Method," Mater. Sci. Eng. C, 33 [5] 2620-25 (2013).

8. S. Santhosh and S. Balasivanandha Prabu, "Thermal Stability of Nano Hydroxyapatite Synthesized from Sea Shells through Wet Chemical Synthesis," Mater. Lett., 97 121-24 (2013).

9. M. R. Saeri, A. Afshar, M. Ghorbani, N. Ehsani, and C. C. Sorrell, "The Wet Precipitation Process of Hydroxyapatite," Mater. Lett., 57 [24-25] 4064-69 (2003).
10. M. Sivakumar, T. S. Sampath Kumar, K. L. Shantha, and K. Panduranga Rao, "Development of Hydroxyapatite Derived from Indian Coral," Biomaterials, 17 [17] 170914 (1996).

11. D. Ulfyana, F. Anugroho, S. H. Sumarlan, W. A. Nugroho, and Y. Wibisono, "Bioceramics Synthesis of Hydroxyapatite from Red Snapper Fish Scales Biowaste Using Wet Chemical Precipitation Route," IOP Conf. Ser. Earth Environ. Sci., 131012038 (2018).

12. Y. Xu, D. Wang, L. Yang, and H. Tang, "Hydrothermal Conversion of Coral into Hydroxyapatite," Mater. Charact., 47 [2] 83-7 (2001).

13. S. Kongsri, K. Janpradit, K. Buapa, S. Techawongstien, and S. Chanthai, "Nanocrystalline Hydroxyapatite from Fish Scale Waste: Preparation, Characterization and Application for Selenium Adsorption in Aqueous Solution," Chem. Eng. J., 215-216 522-32 (2013).

14. A. Shavandi, A. E. D. A. Bekhit, A. Ali, and Z. Sun, "Synthesis of Nano-Hydroxyapatite (nHA) from Waste Mussel Shells Using a Rapid Microwave Method," Mater. Chem. Phys., 149 607-16 (2015).

15. C. Piccirillo, R. C. Pullar, D. M. Tobaldi, P. M. L. Castro, and M. M. E. Pintado, "Hydroxyapatite and Chloroapatite Derived from Sardine by-products," Ceram. Int., 40 [8] 13231-40 (2014).

16. S. Mondal, S. Mahata, S. Kundu, and B. Mondal, "Processing of Natural Resourced Hydroxyapatite Ceramics from Fish Scale," Adv. Appl. Ceram., 109 [4] 234 (2010).

17. A. Prasad, B. Devendar, M. R. Sankar, and P. S. Robi, "Micro-Scratch Based Tribological Characterization of Hydroxyapatite (HAp) Fabricated through Fish Scales," Mater. Today Proc., 2 [4-5] 1216-24 (2015).

18. Y. C. Huang, P. C. Hsiao, and H. J. Chai, "Hydroxyapatite Extracted from Fish Scale: Effects on MG63 Osteoblastlike Cells," Ceram. Int., 37 [6] 1825-31 (2011).

19. M. Boutinguiza, J. Pou, R. Comesaña, F. Lusquiños, A. De Carlos, and B. León, "Biological Hydroxyapatite Obtained from Fish Bones," Mater. Sci. Eng. C, 32 [3] 478-86 (2012).

20. A. Noviyanto and D.-H. Yoon, "Metal Oxide Additives for the Sintering of Silicon Carbide: Reactivity and Densification," Curr. Appl. Phys., 13 [1] 287-92 (2013).

21. A. Noviyanto, Y. H. Han, and D. H. Yoon, "Characteristics of $\mathrm{SiC}_{\mathrm{f}} / \mathrm{SiC}$ Hybrid Composites Fabricated by Hot Pressing and Spark Plasma Sintering," Adv. Appl. Ceram., 110 [7] 375-81 (2011).

22. Y. W. Gu, N. H. Loh, K. A. Khor, S. B. Tor, and P. Cheang, "Spark Plasma Sintering of Hydroxyapatite Powders," Biomaterials, 23 [1] 37-43 (2002).

23. Y. Watanabe, T. Ikoma, A. Monkawa, Y. Suetsugu, H. Yamada, J. Tanaka, and Y. Moriyoshi, "Fabrication of Transparent Hydroxyapatite Sintered Body with High Crystal Orientation by Pulse Electric Current Sintering," J. Am. Ceram. Soc., 88 [1] 243-45 (2005).

24. M. Eriksson, Y. Liu, J. Hu, L. Gao, M. Nygren, and Z. Shen, "Transparent Hydroxyapatite Ceramics with Nanograin Structure Prepared by High Pressure Spark Plasma Sintering at the Minimized Sintering Temperature," $J$. Eur. Ceram. Soc., 31 [9] 1533-40 (2011).

25. B. N. Kim, E. Prajatelistia, Y. H. Han, H. W. Son, Y. Sakka, 
and S. Kim, "Transparent Hydroxyapatite Ceramics Consolidated by Spark Plasma Sintering," Scr. Mater., 69 [5] 366-69 (2013).

26. A. A. Gandhi, R. D. Gunning, K. M. Ryan, and S. A. M. Tofail, "The Role of Texturing and Densification on Optical Transmittance of Hydroxyapatite Ceramics," J. Am. Ceram. Soc., 93 [11] 3773-77 (2010).

27. L. L. Hench, "Bioceramics," J. Am. Ceram. Soc., 81 [7] 1705-28 (1998).
28. R. Furushima, K. Katou, S. Nakao, Z. M. Sun, K. Shimojima, H. Hosokawa, and A. Matsumoto, "Relationship between Hardness and Fracture Toughness in WC-FeAl Composites Fabricated by Pulse Current Sintering Technique," Int. J. Refract. Met. Hard Mater., 42 42-6 (2014).

29. M. E. Launey and R. O. Ritchie, "On the Fracture Toughness of Advanced Materials," Adv. Mater., 21 [20] 210310 (2009). 